\title{
Zorgelijke kwesties in de psychologie
}

Citation for published version (APA):

van Heerden, J. (2003). Zorgelijke kwesties in de psychologie. Maastricht University. https://doi.org/10.26481/spe.20031017jh

Document status and date:

Published: 17/10/2003

DOI:

10.26481/spe.20031017jh

Document Version:

Publisher's PDF, also known as Version of record

\section{Please check the document version of this publication:}

- A submitted manuscript is the version of the article upon submission and before peer-review. There can be important differences between the submitted version and the official published version of record.

People interested in the research are advised to contact the author for the final version of the publication, or visit the DOI to the publisher's website.

- The final author version and the galley proof are versions of the publication after peer review.

- The final published version features the final layout of the paper including the volume, issue and page numbers.

Link to publication

\footnotetext{
General rights rights.

- You may freely distribute the URL identifying the publication in the public portal. please follow below link for the End User Agreement:

www.umlib.nl/taverne-license

Take down policy

If you believe that this document breaches copyright please contact us at:

repository@maastrichtuniversity.nl

providing details and we will investigate your claim.
}

Copyright and moral rights for the publications made accessible in the public portal are retained by the authors and/or other copyright owners and it is a condition of accessing publications that users recognise and abide by the legal requirements associated with these

- Users may download and print one copy of any publication from the public portal for the purpose of private study or research.

- You may not further distribute the material or use it for any profit-making activity or commercial gain

If the publication is distributed under the terms of Article $25 \mathrm{fa}$ of the Dutch Copyright Act, indicated by the "Taverne" license above, 
Zorgelijke kwesties in de psychologie 


\section{Colofon}

Basisontwerp en realisotie: Unigrophic, universiteit Maastwicht

$15 B N 90=5687+866-x$

NUR 770

Alle rechten woorbehowden. Niets, wit deze witgawe mag worden verwedvoudigd, opgeslagen in een geautomatiseerd gegevens bestand of opertabar gemaakt, zonder woorafgoonde schriftelifke toestemming van de auteur of uitgever. 


\section{Zorgelijke kwesties in de psychologie}

Rede

uitgesproken bij de aanvaarding van het ambt van gewoon hoogleraar in de algemene psychologie aan de Faculteil der Psychologie van de Universiteit Maastricht op 17 oktober 2003

door

Jaap van Heerden 


\section{Zorgelijke kwesties in de psychologie}

Meneer de Rector, Dames en Heren,

Sigmund Koch publiceerde in 1981 een artikel over de aard en beperkingen van psychologische kennis. Dat artikel was de uitgeschrevern versie van een toespraak die hij hield bij zijn aantreden als president van de afdeling "algemene psychologie" en de afdeling "filosofische psychologie" van de American Psychological Association in 1979. Dat is dus bijna 25 jaar geleden. Koch betoogt dat er op pijnlijke en beschamende wijze iets mis is met verwerving van wetenschappelijke kenuis binnen de psychologie. Zijn argumentatie is zeer algemeen van aard en zou dus elke academische discipline kunnen betreffen, maar hij beperkt zich tot de psychologie omdat hij daar het meeste van af weet en als psycholoog tenslotte tot psychollogen spreekt, zij het met een duidelijke interesse in het algemene en filosofische aspect van hun vak. $1 \mathrm{k}$ wolg hem in deze beperking.

De psychologie blijkt op betrekkelijk karakterloze wijze kennis te verzamelen die eigenlijk geen betekenis heeft. En zij vermijdt vragen die wel betekenisvol zijn. Als dit waar is, is dat niet normaal, zou je zeggen. Koch windt er geen doekjes om dat hij het gedrag van onderzoekers in de psychologie abnormaal vindt in de klinische betekenis van dat woord. Hun afwijkend gedrag wordt gekenmerkt door veertien symptomen, die bij wijze van spreken zo in de DSM IV, het standaard diagnostisch statistisch handboek voor psychische kwalen, kunnen worden opgenomen. Ik noem er een paar die saillant geacht kunnen worden. Jargon en woordmagie. Voorkeur voor eenvoudige gevallen in de dwaze verwachting dat de oplossing van ingewikkelder gevallen nu vanzelf volgt. Blind vertrouwen in methodologische regels die de rol van de onderzoeker als zelfstandige geest overbodig maken. Totalle amnesle voor de beperkingen die men aan een verschijnsel heeft opgelegd teneinde thet in een mathematisch model te passen. Volslagen afwezigheid van het besel; dat psychologische kennis iets moet betekenen.

De zelf verkozen banalisering van de psychologie is zo algemeen en persistent dat Sigmund Koch het moment gekomen acht de psychologie onderwerp te maken van een cognitieve psychopathologie, die hulp moet bieden. De vermijding van uitdagende malar ook onzekerheid 
brengende vragen schept het syndroom van "ameaningful thinking": waarbij kennisproducten door strikte regulering en methodefetisjisme as uniforme consumptiewaren van de lopende band rollen. In betekenisvol onderzoek is er een levendige, hartstochtelijke en verrijkende relatie met het object van onderzoek. Maar waarom merk je daar zo weinig van in de psychologie en waarom overheerst de nietszeggendheid met harde hand. Dat komt, zoals zo valk in dit leven als de resultaten tegenvallen, door dubieuze contacten. Wolgens Koch heeft de psychologie de natuurlijke band met problemen die de mensen echt bezighouden op alanwijzing van de wetenschapsfilosofie of wat daar voor doorging, radicaal doorgesneden. Dat komt door een eigenaardigheid van de problemen, die mensen diepgaand fascineren. Die problemen zijn namelijk onvermijdelijk en bindend en tegelijk onoplosbaar. Ze lijken op de antinomieen die ooit door Immanuel Kant zijn geformuleerd, met als klassieke illustratie de vraag of het heelal naar tijd en ruimte begrensd of onbegrensd is. Als je zulk soort wragen in enigerlei zin beantwoordt, merk je terstond dat je net zo goed het tegendeel had kunnen beweren. Deze vragen zijn dus onbeslisbaar en toch beheersen ze voor kortere of langere tijd ons leven. Niemand ervart ze als betekenisloos omdat er geen definitieve oplossing voor is. leder normaal mens ervalart de wervende kracht, die er van uitgaat. Binnen de psychologie zijn problemen van deze aard in grote getale aanwezig: "wanneer is een motief zuiver", "wie ben ik", "wat doe ik hier in dit leven", "tot waar reikt mijn verantwoordelijkheid", "waarom heb ik deze ouders", "leef ik noodzakelijkerwijs in mijn eigen tijd", "wat bepaalt mijn gedrag", "ben ik een succes of een mislukking" "hoe zien andere mensen mij", "in welke mate is mijn oprechtheid oprecht", enzovoort. Vragen die traditioneel het dubbelzinnige, problematische en onvoltooide van de menselijke existentie illustreren. Volgens Koch bestaat er in de psychologie een krachtige tendens zulke vragen uit te bannen en te ontkennen omdat problemen met een antinomisch karakter cognitieve onzekerheid scheppen. Het zorgelijke is dat de psychologie het inzicht niet herbergt en niet uitdraagt, dat het menselijk leven door onoplosbare vragen wordt getypeerd "die woor mensen desalniettemin wan grote betekenis zijn. Waarom wordt aan zulke vragen door de psychologie geen aandacht besteed? Dat komt omdat de psychologie zich het dogmatische filosofische standpunt heeft laten aanleunen, dat vragen die onbeslisbaar zijn geen betekenis hebben. "A conspicuous strand in the philosophy, especially the scientific philosophy, of the zoth century has been the view that all questions having presumptive cognitive content but which can be shown to be 
undecidable in principle are meaningless. They are, in other words, $p$ seudoquestions- inguistically illegitimate questionforms." (Koch.op.cit,p.265). Rationele hygiene legt daarom dwingend op dat het menselijk geslacht van zulke illusoire bezigheden wordt verlost. De afwijzing, ook bespeurbaar in het operationalisme en pragmatisme, berust op de leerstelligheid dat een uitspraak pas betekenis heeft als wij kunnen aangeven onder welke woorwaarden hij waar is. "I should like to suggest that such a wiew of the range of the meaningful has had, and must have, crippling entailments for the character of the psychological enterprise."(ibidem, p.266) De psychologie heeft zich laten ringeloren door een filosofie, die tegen elke menselijke ervaring in. simpelweg dicteert wat wel en wat geen betekenis heeft. Daarom verkeert de psychologie volgens Sigmund Koch in zo'n deplorable staat.

Laat ik in de eerste plaats opmerken, dat Koch niet de eerste de beste is. Hij was op het moment dat hij deze toespraak hield reeds een gerenommeerd psycholoog, die met name zijn sporen verdiend had als redacteur van het zesdelige standaardwerk Psychology: A Study of a Science (1959). Hij staat bovendien niet alleen in zijn klacht dat de psychologie haar ware aard verloochent. Men kan die klacht met de regelmaat van de klok beluisteren bij gezaghebbende psychologen, die de veertig gepasseerd zijn. De teneur is steeds dezelfde: gebrek aan autonomie, onderworpenheid aan de verkeerde filosofie, verschraald mensbeeld, verwaarlozing van de oorspronkelijke allure, infiltratie door buitenstaanders met dubieuze belangen. Bij de diagnose van Koch zou je kunnen zeggen dat de psychologie zelfs lijdt onder nachtraeglicher Gehorsam, waarvoor andere slachtoffers in psychoanalyse gaan, omdat de filosofie die hij hekelt in 1980 al lang overleden was.

Het artikel van Sigmund Koch is een beetje wereldvreemd. Hij heeft natuurlik in zoverre gelijk dat in leder leven met een zekere regelmaat vragen opdoemen naar de zim wan het bestaan, het kenmerk van de eigen identiteit en een zinvolie besteding wan de toegemeten jaren. Die vragen raken ons, ondanks het besef dat ze onoplosbaar zijn. Maar het is misschien toch een beetje veel gevraagd van de psychologie te verlangen dat zij in het doen van onderzoek de sporen draagt van dat levensgevoel en van die verscheurdheid tussen kemmende vragen en onvolmaakte antwoorden. Het is misschien ook niet waar dat het logisch positivisme aan de psychologie alle allure ontfutseld heeft. Toch bestaat er een filosofische bemoeienis met de psychologle, die gemak. 
kelijk tot een zekere irritatie aanleiding geeft. Filosofen zijn er betrekkeijk goed in om stellingen, die door de wetenschap worden aanvaard, op zich zelf te Iaten terugslaan, zodat ze paradoxaal worden en onaanvaardbaar. Het zijn eigenlijk allemaal variaties op het thema van de Kretenzer die zegt dat alle Kretenzers liegen. Daar heeft de filosofie het patent op. Het is een zeer verleidelijke strategie; waar ik ook zelf wel eens voor gezwicht ben. Ik zal u een paar voorbeelden geven.

Zo heb ik ooit beweerd dat het Oedipuscomplex bij jongetjes van vier. vijf jaar niet bestaat. Aan die jongetjes wordt de wens toegeschreven hun vader te vermoorden en gemeenschap te hebbem met hun moeder. Naar mijn idee berustte de populariteit van het Oedipuscomplex op de noodzaak de ouderlijke agressie, waarwoor een overwelligende empirische evidentie bestaat, te ontkennen door deze te projecteren op de kleuter woor wiens excessleve agressie jegens zijn ouders nauwelijks enige evidentie bestaat. (Van Heerden,1978). Freud achtte de Dedipusmythe, zoals uitgebeeld in de tragedies van Sophocles, een blijvende obsessie in de mensheidsgeschiedenis. In die mythe voorspelt het orakel dat het kind dat Laios en locaste verwachten zijn vader zall doden en zijn moeder zal huwen. Meteen na de geboorte worden op bevel van Laios en met instemming van locaste de voetjes van het kind doorboord. In die verminkte staat wordt het in thet gebergte achtergelaten in de verwachting dat het een zekere hongerdood zal sterven. De mythe vermeldt clus ouderlijke agressie, die aan de eventuele agressie van het kind voorafgaat. Freud vond die chronologie niet de moeite van het vermelden waard. Vanwalar deze omissie? Ik meende in talrijke psychoanalytische betogen over het Oedipuscomplex zeer simplistisch gearrangeerde beschuldigingen a an het adres van de kleuter te bespeuren en kon tegelijk aannemelijk maken, dat ouders goede redenen kunnen hebben de komst van een kind te betreuren. De vader krijgt er in leder geval een rivaal bij in de strijd am de gunst van de moeder. zou het niet zo kunnen zijn dat de agressie die de vader jegens zijn zoon heeft, door hem als ontoelaatbaar wordt gevoeld en vervolgens middels het psychisch mechanisme van projectie aan de zoon wordt toegedicht. Projectie is een soort bescherming tegen eigen ongewenste verlangens en gevoelens. Door deze toe te schrijwen aan de persoon jegens wie men ze heeft, worden ze verteerbaar en verstoren ze niet langer de gemoedsrust. De psychoanalyse heeft door de aanname van het Oedipuscomplex de vader en de moeder een grote dienst bewezen. Zij heeft de projectle op het kind van de agressieve en erotische wensen jegens het kind 
vergemakkelijkt en gelegitimeerd. Die dienst bewees de psychoanalyse uiteraard ook de psychoanalytici, waaruit hun selectieve voorkeur voor sommige details verklaard kan worden en hun verwaarlozing van andere. Sommige psychoanalytici die ik met mijn idee vertrouwd maakte zeiden, dat dit alles al lang bekend was, andere psychoanalytici dachten dat ik met dit schrijuen solliciteerde naar een psychoanalytische behandeling. Het schrijven van zo'n stuk waarbij je probeert een centrale stelling in een theorie (het Oedipuscomplex) te ontkrachten door een ander deel van de theorie (projectie) te benutten, kan slechts de uitkomst zijn van bedenkelijke redeneerzucht die geen betrokkenheid vereist, zegt men. Dit is allemaal al weer lang geleden.

De psychologie kan er trots op zijn dat zi] bereid en in staat is onderzoek te doen naar de kwetsbaarheid van psychologisch onderzoek.

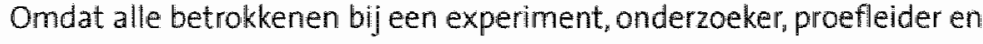
proefpersoon, ook maar gewone mensen zijn met hun eigen particullere zorgen, wensen en verwachtingen, is wanaf het eerste moment van experimentatie het besef van wederzijdse beinvloeding aanwezig geweest. Kan er door de psychische gesteldheid van de betrokkenen geen vertekening ontstaan, die het resultaat in feite waardeloos maakt. Meet men bijvoorbeeld niet eerder de mate waarin een proefpersoon zijn reputatie wenst te beschermen dan zijn authentieke reactie op de onafhankelijke variabele en stuurt de onderzoeker de reacties niet in de richting van de gewenste uitslag? De achterdocht inzake de geldigheid van experimentele resultaten bereikte in de jaren zestig van de vorige eeuw een hoogtepunt in het werk van Robert Rosenthal. Hij woerde vaak zeer geraffineerde experimenten uit om te achterhalen in welke mate onderzoek door de instelling van de betrokkenen wordt gecontamineerd. Een klassiek voorbeeld is het volgende: Rosenthal stuurde de ene groep onderzoekers een aantal ratten die hij kwalificeerde als "mazebright" en de andere een aantal ratten die hij kwalificeerde als "mazedull'. Dat was uit eerder onderzoek gebleken, suggereerde hij. in werkelijkheid waren de ratten willekeurig toebedeeld aan de twee condities en ook niet geoefend in het vinden van de snelste weg in een doolhof. Rosenthal verzocht om een replicatie. De terloops geinduceerde werwachting had effect, want bij het leren wan hun weg in het doolhof bleken de ratten die als slim beschouwd mochten worden het significant beter te doen dan de ratten die stom genoemd waren. Onderzoekers kumnen zich dus kennelijk laten leiden door de verwachting die bij hen wordt gewekt. Door die verwachting gaan zij zich anders gedragen. be 
werklaring van het witeenlopend gedrag der ratten is immers, dat proefleiders de slim geachte exemplaren zachtaardiger behandelen, wat hun prestatie ten goede komt. De irvloed, die de verwachting van de onder zoeker heeft, wordt wel het Rosenthal effect genoemd. Dat zo'n effect bestaat is op zich zelf vervelend genoeg. Maar het kon natuurlijk niet uitblijuen dat iemand opmerkte, dat experimenteell onderzoek naar de mate waarin onderzoekers zich door hun verwachting laten leiden zelf op een verwachting berust, die het onderzoek stuwt in de richting die de onderzoeker wenst. Experimenteel onderzoelk naar het Rosenthal effect creeert het meta-Rosenthal effect. En zo komt men onvermijdelijk in een eindeloze regressie terecht. De filosoof Michael Martin (1970) heeft dat haarscherp uiteengezet. Dit is een zeer onaangename complicatie. Dat de soep uiteindelijk niet zo heet gegeten werd als zij werd opgediend is een empirisch historische bijkomstigheid, die eigenlijk niets afdoet aan de typische intellectuele bijdrage die men van een fillosoof kan verwachten. Er ligt een vast schema ten grondslag aan zijn commentaar, dat steeds anders kan worden ingevuld. Om nog een voorbeeld te noemen: als het honorabel en onvermijdelijk is bij alle uitspraken te streven naar weerlegging, zoals Karl Popper wil, dan zou men ook moeten streven naar weerlegging van deze uitspraak. Falsificatie van het falsifica-

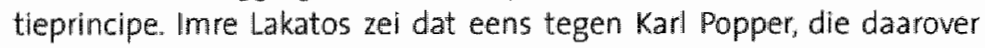
zeer kwaad werd en mijns inziens terecht, malar dat laat ik hier verder onbesproken.

De filosofische bemoeienis met de psychologie is van alle tijden en dat is niet zo vreemd als men bedenkt, dat de autonomie van de psychologie pas dateert van 1879, toen Wilhelm Wundt zijn Institut fuer Experimentelle Psychologie te Leipzig stichtte. De psychologie kreeg daarmee een eigen domein. Behoorde de psychologie woorheen integraal tot de filosofie, er werd vanaf 1879 in toenemende mate distantie gecreëerd. Als filosofen zich nog met de psychologie bemoeiden, bemoeiden zi] zich in feite met problemen buiten hun eigen wakgebled en daarbij genoten zij niet zoiets als ouderlijk gezag over hun geestes. kind. De discussie over de ard en de misleidende kenmerken van de Mueller-Lyer illusle is daarvan een goed voorbeeld. Doordat twee lijnstukken van gellike llengte aan de eindpunten tegengesteld gevederd worden, ziet de waamemer ze niet meer als even lang. Deze optische illusie werd voor het eerst beschreven door F.C. Mueller Lyer in 1889. Pas echt bekend werd zij toen Franz Brentano er in 1892 een bespreking aan wildde. Een eindeloos debat was het gevolg, gevoerd door psychologen, 
fysiologen, natuurkundigen en filosofen. Maar filosofen namen in die discussie geen bevoorrechte positie in. Zij waren gewoon deelnemers aan het debat over de ware aard van een verschijnsel dat als psychologisch erkend werd, hetgeen alleen al blijkt wit het feit dat alle bijdragen in de beginjaren van de polemiek werschenen in het Zeitschrift fuer Psychologie. Het ging niet om een filosofische kwestie ais "Is de menselijke waarneming betrouwbaar als bron van kennis", het ging om de technische vraag, waardoor de illusie wordt veroorzaakt. De filosofische bemoeienis was dus inhoudelijk. Het probleem stond centraal en het probleem was psychologisch. In schril contrast met die belangeloze filosofische deelname aan het debat staat de bemoeienis van het logisch positivisme, dat ter uitbanning van de metafysica de hele wetenschap en dus ook de psychologie onder zijn welwillende curatele plaatste. Binnen het logisch positivisme wordt de vraag beslissend of de psychologie wel een echte wetenschap is, of zij kan woldoen aan de eisen van bewijsvoering, of zij er in kan slagen haar begrippen te operationaliseren en of haar theorieen wel de formele structuur van een theorie hebben. De fillosofische belangstelling is van de inhoud naar de vorm verschoven. En ook nu nog wordt veel filosofische kritiek gekenmerkt door dit vormelijke aspect. Maar er is ook een kentering te bespeuren. Ik geloof dat in menig opzicht de huidige psychologie in een situatie verkeert, die te vergelijken valt met de jaren rond 1890 , toen een grote verscheidenheid aan geleerden zich op de verklaring van de Mueller-Lyer illusie stortte. Psychologische problemen staan weer centraal en er is nu, net als toen, een grote inhoudelijke betrokkenheid vanuit een veelheid aan disciplines: neurologie, filosofie, linguistiek, logika, blalogie en hersenfysiologie om er slechts enkele te noemen. De deelnemers aan de huidige discussie hebben allemaal hun elgen idee wat in de psychologie belangrijk zou moeten zijn, waar de accenten dienen te liggen en hoe een oplossing binnen bereik ligt, als men maar het juiste paradigma kiest. Zij dragen ook allemaal hun eigen zorgelijke kwesties de psychologie binnen of kiezen uit de gesetiledenis van de psychologie een kwestie die naar hun inzicht de psychologie ten onrechte achter zich heeft gelaten. Ik wil daar een woorbeeld van bespreken. Het betreft een verschijnsel waarvan de psychologie zelf verre van zeker is of het bestaat, al wordt met de term ook binnen de psychologie gemakkelijk geschermd. Het betreft het verschininsel werdringing.

De neuroloog Ramachandran (1998) merkt op dat zich een typisch psychologisch verschijnsel voor kan doen bij patiënten die in de rechter- 
hersenhelft cen beroerte hebben gehad, die resulteert in een linksijijige werlamming. Dat verschijnsel doet zich niet woor bij patiënten, die in de linker hersenhelft een beroerte kregen en rechtszijdig zijn verlamd. Dat verschijnsel is de ontkenning van het ziek zijn. Voorzover bij deze patiërten ontkenning voorkomt, komt hij uitsluitend bij patiènten voor die linkszijdig verlamd zijn. Het is een vorm van anosognosia, het niet onderkennen van het ziek zijn. Er zijn patiënten, die volhouden dat zij allerlei taken normaal met hun verlamde linkerhand kunnen uitvoeren, als hen daarnaar gevraagd wordt en negeren dat de uitslag op het tegendeel wijst. Waarom antkennen zij dat zij verlamd zijn? Zij werkeren doodgemoedereerd in een toestand van acuut en extreem zelfbedrog. Een onaangename waarheid wordt afgewend, niet toegelaten, verdrongen. Ter bescherming van het zelfbeeld benut de patiënt het afweermechanisme van verdringing. Ookall zou je het verschijnsel verdringing aamvarden, dan nog blijft onwerklaard, waarom in de klinische praktijk van Ramachandran verdringing in deze hevige vorm vrijwel uitsluitend bij mensen met een linkszijdige verlamming voorkomt. Vanwaar die asymmetrie. Hier moet de neurologie te hulp geroepen worden. Gegeven is dat in het normale gezonde leven er een soort taakverdeling bestaat tussen de hersenhelften inzake de verwerking van informatie. Onder het permanente bombardement van prikkels moet nieuwe informatie worden ingepast in ons kennisbestand, terwijl tegelijkertijd het bestaande wereldbeeld zoveel mogelijk intact gellaten moet worden. "The coping strategies of the two hemispheres are fundamentally different. The left hemisphere's job is to create a belief system or model and to fold new experiences into that belief system. If confronted with some new information that doesn't fit the model it relies on Freudian defense mechanisms to deny, repress or confabulate - anything to preserve the status quo. The right hemisphere's strategy, on the other hand, is to play "Devil's Advocate", to question the status quo and look for global inconsistencies. When the anomalous information reaches a certain threshold, the right hemisphere declides that it is time to force a complete revision of the entire model and start from scratch. (.....) Now consider what happens if the right hemisphere is damaged. The left hemisphere is then given free rein to pursue its denials, confabulations and other strategies, as it normally does." (op.cit.p.136) Patienten met een linkszijdige verlamming kunnen hun wereldbeeld dus niet herzien, waarin hun handicap een plaats zou moeten vinden, omdat hun rechterhersenhelft beschadigd is "with its mechanisms for detecting discrepancies." Wordt een patiënt getroffen door een beroerte in de rechter- 
hersenhelft dan wordt het door de rechterhelft gekoesterde realliteitsbesef uitgeschakeld en heeft de linkerhelft in zijn conservatisme de vrije hand. Wanneer Ramachandran patienten met een eenzijdige werlamming vraagt een dienblad met glazen water wast te houden, dan brengen patiënten die hun kwaal niet ontkennen hun hand direkt naar het midden van het blad om het evenwicht te vinden, maar ontkennende patiënten reiken met hun rechter hand (bestuurd door de intacte linkerhersenhelft) direkt naar rechterzijde vam het blad, terwijl het dienblad aan de andere kant dus niet ondersteund wordt. Geen prettige proef in bed. Uitgaande van deze en soortgelijke klinische observaties bepleit Ramachandran om binnen de psychologie opnieuw aandacht te besteden aan het verschijnsel verdringing.

Ramachandran staat in de erkenning van het verschijnsel verdringing niet alleen. De filosoof John Searle, die onder psychologen wooral bekend is door zijn gedachtenexperiment uit 1980 , waarmee hij probeerde aan te tonen dat een computer geen bewustzijn kan worden toegekend, zegt in een latere publicatie geheel terloops dat het causaal vermogen van een onbewuste mentale toestand om bewust te worden geblokkeerd kan worden door verdringing of een hersenbloeding. "When we describe something as an unconscious intentional state, we are characterizing an objective ontology in virtue of its causal capacity to produce consciousness. But the existence of these causal features is consistent with the fact that in any given case these causal powers may be blocked by some interfering cause, such as psychological repression or brain damage" (Searle,1992,p.16o). Verdringing is lets dat zomaar kan gebeuren net als een beroerte. En de neuroloog Gerald Edelman (1992) vindt dat binnen zijn theorie over de opbouw van het bewustzijn vanzelfsprekend een functie toekomt alan het mechanisme van verdringing am invloeden te weren die het zelfbeeld bedreigen. "Repression, the selective inability to recall, would be subject to recategorizations that are strongly value-laden. And given the socially constructed nature of higher order consciousness, it would be evolutionary advantageous to have mechanisms to repress those categorizations that threaten the efficacy of self-concepts" (op. cit. p.745).

De drie hier aangehaalde auteurs worden alom geprezen om hun baanbrekend werk inzake de betrekkingen tussen hersenen en bewustzijn. Zij reppen blijmoedig van verschijnselen, waarvan het bestaan onder psychologen op zijn zachtst gezegd onstreden is. Halalt de psy- 
chologie in het genot van deze belangstelling het paard van Troje binnen? Het is gemakkelijk gezegd, dat in een voorkomend geval verdringing heeft plaatsgevonden maar het is voor de psychologie verre van duidelijk wat de reikwijdte wan zo'n veronderstelling moet zijn. Ondanks een grote welwillendheid het verschijnsel au serieus te nemen en ondanks de inzet om tot eenduidige experimentatie te komen, is de psychologie er tot op heden niet in geslaagd het verschijnsel van verdringing daadwerkelijk aan te tonen. Dat zegt natuurlijk niet dat het verschijnsel daarom niet bestaat, maar de roep om zuinigheid in het veronderstellen wan oorzakelijke krachten laat zilch onvermijdelijk steeds duidelijker horen. Dit is een empirisch probleem, dat in hoge mate getypeerd wordt door de lastige vraag hoe gemotiveerd wergeten onderscheiden moet worden van alledaags geheugenverval en toevallige leerntes in de herinnering. En ook begripsmatig wordt de onderzoeker met grote problemen geconfronteerd, die direkt woortwloeien uit het idee van bewuste of onbewuste mentale werkzaamheid. Vergeet niet dat oorspronkelijk verdringing beschouwd werd als een mechanisme en ook nu nog handhaaft men incidenteel die woordkeus. Verdringing is een mechanisme onder de afweermechanismen, zie Edelman en Ramachandran. Als bij veronderstelling het verschijnsel bestaat, in welke zin is het dan een mechanisme. Allerlei vragen lijken dan gewettigd. Neemt het tijd in beslag, kost het energie, heeft het ais mechanisch proces een begin en een eind, kan het onderbroken worden. Kan men zeg. gen, "Kitty was bezig iets te verdringen. Toen ging de telefoon. Dat leidde tot een korte onderbreking. Gelukkig maar, want zo was Kitty nog net in staat na beëindiging van het gesprek de draad weer op te pakken en de verdringing te voltooien". Kan het proces versneld worden of vertraagd. Kan het ten onrechte worden toegepast. Kan het mislukken, kan het falen. Kan het gecombineerd worden met andere afweermechanismen en zo ja, welke. Leidt een combinatie tot optimalisering of juist niet.

Bij elke voorstelling van verdringing als een beschikbaar mechanisme zijn deze vragen - hoe absurd ook - onontkoombaar. Je kan aanbevelen deze vragen niet te stellen, mar dan is het misschien nog beter verdringing niet als een mechanisme voor te stellen waar het brein over beschikt. Dat hoeft natuurlijk ook niet. Men zou als altematief verdringing kunnen voorstellen als a and uiding van een regel, vergelijkbaar met een grammaticale regel, die niet zozeer gepostuleerd wordt om een mentale activiteit te beschrijuen, maar om de welgevormdheid van de 
uitkomst te verklaren. Natuurlijk kan men ook de vraag stellen hoe en of mensen deze regel toepassen, maar de afhandeling van deze vraag geschiedt binnen een afgebakend domein. De psycholinguirstiek concentreert zich op het proces van taalproductie, de linguistiek op de kwaliteit van de regel binnen een geexpliciteerde grammatica. Zo'n taakverdeling zou men ook bij werdringing kunnen benutten. Denk ter vergelijking aan de grammaticale regel die de omzetting van een actieve zin in een passieve zin vastlegt. Men kan zich bezighouden met de vraag of iemand die regel daadwerkelijk toepast en bij toepassing van die regel onderbroken kan worden of de kluts kwijt raakt. Maar men kan zich ook met de vraag bezighouden of die regel toereikend is om binnen een grammatica de welgevormdheid van het passief, gegeven het actief, voor alle denkbare omzettingen te typeren. Als men verdringing op deze wijze wil onderzoeken, wordt de vraag natuurlijk, hoe luidt de regel die verdringing wastlegt dan.

Het zijn trouwens niet alleen betrekkelijke buitenstaanders die aandacht vragen voor verdringing. Ook menig psycholoog doet dat. Steven Pinker (2002) neemt de afweermechanismen op in zijn rijtje evolutionaire onvermijdelijkheden. "The prevalence of defense mechanisms, self-serving biases, and cognitive dissonance reduction, by which people deceive themselves about their autonomy, wisdom and integrity." (op. cit p. 294). Die zullen, hoe je de mens ook wilt vormen, altijd blijven bestaan. Jean Piaget vond reeds in 1973 dat het het begrip verdringing niet alleen binnen de klinische psychologie maar ook binnen de ontwikkelingspsychologie van toepassing was, want naar zijn bevindingen bestaat er zoiets als een leeftijdsafhankelijke cognitieve verdringing. Op een bepaalde leeftijd kunnen kinderen een vrij lastige motorische taak perfect uitvoeren, waaruit beheersing blijkt, maar zij accepteren de expliciete beschrijving ervan niet, omdat deze begrippen bevat die strijdig zijn met hun technisch wereldbeeld van dat moment. De cognitief psycholoog Bernard Baars, die een model van het bewustzijn ontwikkeld heeft, waar ik zo direct nog op terug kom, ruimt binnen zijn model ook een plaats in voor verdringing, simpelweg omdat het past en dat is het dan.

Het is de vraag of al deze auteurs met verdringing hetzelfde bedoelen en vooral of zij op dezelfde wijze verdringing een plaats geven in de keten van oorzak en gevolg. Bij een eerste inventarisatie bijken zij daarin aanmerkelijk te verschillen. De een acht verdringing zonder meer 
heilzaam in evolutionaire zin (Edelman, Pinker), de ander ziet het als corsprong van veel ellende amdat het verdrongene, hoe dan ook, ontregelend werkt (Anna Freud), en een derde ziet verdringing als een onver * mijdelike fase in de cognitieve ontwikkeling. Een fase die langs natuur. lijke weg even gemakkelijk opkomt als weer verdwijnt.(Piaget), een vier" de ziet het als een verschijnsel dat ons even gemakkelijk kan treffen als een hersenbloeding (Searle). En zo kunnen we nog well even doorgaan. Het is een taak van de algemene psychologie, lijkt mij, in zo'n grote verscheidenheid enige samenhang te brengen.

Aan de hand van een beperkt en binnen het geheel van de neurowetenschap zeer miniem verschijnsel als verdringing, kan men toch zeer adequat beschrijven welke conceptuele zwakte de neurocognitie bedreigt. Dat is de mereological fallacy, opgespoord door Bennett \& Hacker (2003). Deze dwaling houdt in dat men aan delen van de persoon en dan vooral aan zijn hersenen of delen wan zijn hersenen psychologische attributen toekent, die men eigenlijk uitsluitend aan de persoon zelf toe kan kennen. Zo kan men wel zinvoll opmerken, dat Jan zijn zorgelijke toestand niet onder ogen wil zien, maar niet dat de linkerhersenhelft wan Jan de zorgelijke toestand van Jan niet onder ogen wil zien. Zo ook is het een woorbeeld van de mereological fallcy om te denken dat het onbewuste een initiatief neemt of dat neuronen twiffelem. Bennett en Hacker merken op dat vooral het onderzoek met split brain patiënten tot grote descriptieve verwarring leidt. Rechts ziet dit en links ziet dat, rechts kiest woor $A$ en links kiest voor $B$, etc. Maar, "it should be obvious that the hemispheres of the brain cam neither see nor hear. They cannot speak or write, let alone interpret anything or make inferences from information. They cannot be said to be aware or unaware of anything. They do not make choices or judgements of grammaticality, and they are neither knowledgeable or ignorant" (op. cit. p. 391). Het is natuuriijk het subject, de persoon die oordeelt, kiest, onwetend is en besluit. Mogelijk niet perfect of consistent onder alle omstandigheden omdat zijn hersenhelften operatief zijn gescheiden, maar desalniettemin oordeelt hij en niet allerlei instanties in hem.

Het is van belang te bedenken dat deze misleidende formuleringen ons zeer gemakkelijk afgaan. Ook Ramachandran is niet geheel opgewassen tegen de verleidingen van de mereological fallacy wanneer hij in het daamet gegeven citaat beschrifft hoe de rechterhelft op een gegeven moment besluit dat het roer om moet nu de inconsistenties 
zich opstapelen en hoe de linkerhersenhelft gemalkkelijk confabuleert, ontkent en verdringt.

Eerder noemde ik Bernard Baars, over wiens model van het bewustzijn ik nog iets wil zeggen. Baars $(1988,1996)$ is een wan de grondleggers wan de opwatting, dat het bewustzijn bewerkstelligd wordt door een systeem van gedistribueerde parallel werkende onbewuste modules. Dat systeem bevat een globale werkruimte of een werkgeheugen, door Baars ook wel metaforisch aangeduid als een prikbord of een schoolbord woor mededelingen, die voor ledere module van belang kunnen zijn. Wat op dat schoolbord komt te staan is woor ieder subsysteem of woor iledere module beschikbaar. Uw bewustzijn wan wat ik net zeli de worige zin, is de beschikbaarheid van die zin voor subsystemen, die van mijn formulering bijvoorbeeld de syntaxis analyseren, de betekenis vaststellen, het emotionele en intellectuele belang onderkennen en de mogelijke implicaties berekenen. De globale beschikbaarheid van informatie is wat wij bewustzijn noemen. Dennett (2001), die sympathie voor deze theorie heeft, zegt dat je misschien nog gemakkelijker kunt begrijpen wat het onderliggende idee is door een vergelijking te trekken met roem. De informatie die op een geven moment in het globale werkgeheugen beschikbaar is voor een gemeenschap van specialistische modules of subsystemen, is dan net zollets als de Bekende Nederlander die door zijn positie op de Sterrenbeurs even beroemd is $1 k$ hoop dat deze theorie het langer uithoudt dan dat televisieprogramma. Bewustzijn is roem ("fame in the brain"), bewustzijn is het vergankelijke Bekende Nederlanderschap, bewustzijn is de globale toegankelijkheid voor alle subsystemen in een groot informatieverwerkend systeem "dat wij het menselijk brein noemen.

Dit idee stuit op verzet bij andere theoretici omdat in een informatieverwerkend systeem, hoe je het ook verbeeldt, de subjectieve ervaring ontbreekt: hoe het is om over zo'n systeem te beschikken of te registreren wat je daarin beleeft. Dat is het bewustzijn. Dennett vindt dat mensen, die zulke dingen zeggen, in therapie moeten. Tegen zoveel onwil is geen wetenschappelijk argument toereikend. Een therapeut, gespecialiseerd in zucht tot tegenspraak zou hier heilzaam werk kunnen doen. Dennett meent dat beschikbaarheid van informatie bewustzijn is. Searle (1995) daarentegen zegt dat beleving essentieel is, that is the problem of consciousness. In feite ontkent, volgens hem, Dennett al zolang als hij zich met het probleem bezighoudt, het bestaan van het 
bewustzijn en dat is al ewenzeer ziekelijk. "I regard Dennett's denial of the existence of consciousness not as a new discovery or even as a serious possibility but rather as a form of intellectual pathology" (op.cit. p. 58 ).

Daarmee zijn wij na 25 jaar eigenlijk weer teruggekeerd bij Sigmund Koch. Er is iets hetzelfde geblewen en er is lets veranderd in de tussentijd. Filosofen zijn van vrijblijuend commentator op de status van de psychologie deelnemers a an het debat geworden over uitdagende psychologische problemen, net als hersenfysiologen, linguisten, biochemici, logici en biologen. De participatie is massaal. Als men de huidige discussie overziet dan lijkt het of aan het rijtje Kantiaanse antinomieën, waar de psychologie eertijds te weinig oog woor had, een antinomie toegevoegd kan worden die aan de psychologie zelf ontspringt: het bewustzijn. Als je bewijst of probeert te bewijzen dat het subjectieve geobjectiveerd kan worden, wat een redelijk wetenschappelijk doel is, raak je het subjectieve per definitie kwijt. Maar als je elke objectivering afwijst plaats je het subjectieve buiten het wetenschappelijk domein. En tenslotte, Koch meende dat de psychologie eens een psychiater zou moeten raadplegen, nu vindt Dennett dat mensen als Searle en Searle dat mensen als Dennett eens in therapie moeten. Want het moet niet te gek worden. 


\section{Ik wil zoals te doen gebruikelijk bij een oratie eindigen met een dank- betuiging.}

In de eerste plaats will ik mijn erkentelijkheid uitspreken aan al diegenen, die aan mijn benoeming hebben bijgedragen door het laten bijken van hun vertrouwen in mij. I $\mathrm{k}$ wil niet zeggen dat dat wertrouwen een zorgelijke kwestie is, maar ik ben er wel van doordrongen dat ik het niet moet beschamen.

Dat ik hier sta als hoogleraar in de psychologie heb ik aan veel men* sen te danken maar de eerlijkheid gebiedt twee leermeesters direct te noemen: Johan Barendregt en Nico Frijda. Mijn oorspronkelijke promotor, Johan Barendregt, in 1982 vlak voor de voltooiing van mijn proefschrift overleden, heeft mij door zijn geestig malar ook ernstig beleden wantrouwen in de voortgang wan de psychologie altijd zeer geinspireerd. Wat hij niet kon was gewichtig doen en van hem heb ik geleerd dat de psychologie welvaart, zolang psychologen dat dan ook nalaten. Nico Frijda, bij wie ik tenslotte promoveerde, heeft mij altijd geimponeerd door de levendigheid wan zijn kritiek ook al kostte het soms enige moeite het hoge tempo wa arin de argumenten elkaar opvolgden, maar ook soms tegenspraken, bij te houden. In het vertoon van stij|vol en onnadrukkelijk redeneren schuilt een ernst, die zich als een onvoorwaardelijke toewijding aan de psychologie openbaart. Nico Frijda heeft mij eigenlijk persoonlijk voorgedaan dat de psychologie zin heeft.

Ik heb aan de Universiteit van Amsterdam gewerkt met wijf hoogleraren in de Psychologische Methodenleer: Adriaan de Groot, Ullin Place, Fred Kerlinger, Don Mellenbergh en Peter Molenaar. Hoewel zij allen mij nadrukkelijk verzekerden dat ik er bij hoorde, hebben zij mij altijd mijn eigen gang laten gaan. Van hun expertise begreep $i k$ niet meer dan de helft maar mogelijk gold dat ook omgekeerd. Dat zij van die twee ontbrekende helften geen punt hebben gemaakt, toont op natuurlijke wijze de elasticiteit van hun gezag.

De leden van de vakgroep Methodenleer, onder wie ik nadrukkelijk ook Pia Dorman en Ineke wan Osch wil noemen, hebben mijn leven intellectueel en sociaall verrijkt. Met enkelen heb ik zelfs, zoals het zich nu laat aanzien, vriendschap gesloten woor het leven: Pieter Koele, Wulfert van den Brink, Fred Cornelisse en Johan Hoogstraten. Over de laatste moet ik nog dit zeggen. Johan Hoogstraten, hoogleraar in de experi- 
mentele methodenleer, heeft mij geintroduceerd in de wereld van het proefondervindelijk onderzoek. Daaruit is een vriendschap ontstaan die zeker oprecht is maar ook permanent onderworpen aan een vrijwillig verkozen ondermijning en bestrijding. Op buitenstaanders moet dat een vreemde indruk maken, maar ik geloof dat wij veel plezier ontlenen aan het raffinement waarmee dat gebeurt.

Van de Alo' en Oio's die ik mede begeleidde, Dick Ruimschotel, Fenna Poletiek, Denny Borsboom en Maarten Speekenbrink heb ik veel, maar niet alles geleerd.

En dan nu Maastricht. Ik heb een hoge dunk van mijn collega hoogleraren aan de Faculteit der Psychologie. Met velen heb ik een bijzonder prettig contact. Ik twijfel er niet aan dat wij goed zullen kunnen samenwerken, als dat nodig mocht zijn.

Met de medewerkers in mijn directe omgeving, Rob de Vries, Harry Smit, Peter Vermeer, Gerda Galenkamp en Anton de Vries krijgt de samenwerking steeds duidelijker gestalte. Met zoveel geleerdheid in zo'n kleine groep moet het mogelijk zijn snel een afdeling Theorie en Geschiedenis te formeren.

In de student van Maastricht herken ik de universele student. Het contact tussen ons is groeiende. $\mathrm{k}$ zal er alles aan doen het studeren lonend te maken. Er is een leeftijdsverschil tussen ons. Maar bedenk dat de firma Blokker te Maastricht mij zonder enige terughoudendheid de zogenaamide Starters set elementair keukengerei verkocht, bedoeld voor hen die voor het eerst zelfstandig gaan wonen. Als deze vertegenwoordiger van het Nederlandse midden-en kleinbedrijf van dat leeftijdsverschil geen probleem maakt, wie zijn wij om dat wel te doen.

Tot slot mijn gezin. Ik heb een zorgzame, voortreffelijke en onafhankelijke vrouw, een charmante en zeer geestige dochter, twee kordate zonen en een zeer bijzondere kleinzoon van drie, die mij regeimatig - onbekommerd en woorzover ik kan nagaan zonder enige redelijke grondeen dommerd noemt. Ik mag de voorzienigheid wel danken dat ik met hen in aanraking gekomen ben. 


\section{Literatuur}

In volgarde van verwijzing in de tekst

- Sigmund Koch (1981), The Nature and Limits of Psychological Knowledge, American Psychologist, 36, 3, 257-269

- Jaap van Heerden (1978), Suppose the Oedipus Complex were Just a Projection, inquiry, 21, 4, 461-472

- Michael Martin (1970). The Philosophical Importance of the Rosenthal Effect, Journal for the Theory of Social Behoviour, 7, 1, 81-97

- V.S.Ramachandran (1998), Phantoms in the Brain. London: Fourth Estate

- John Searle (1992). The Rediscovery of the Mind Cambridge Mass. MIT press

- Gerald Edelman (1992), Bright Air, Brilliant Fire. London: Penguin Press

- Steven Pinker (2002), The Blank Slate. London: Penguin Books

- M. R. Bennett and P. M. S. Hacker (2003), Philosophical Foundations of Neuroscience. Oxford: Bllackwell

- Bernard Baars (1988), A Cognitive Theory of Consciousness. Cambridge: CUP

- Bernard Baars (1996), Understanding Subjectivity: Global Workspace Theory and the Resurrection of the Observing Self, Journal of Consciousness 5tudies, $3,3,211-216$

- Daniel Dennett (2001), Are We Explaining Consciousmess Yet? Cognition $79,1,221-237$

- John Searle (1995). The Mystery of Consciousness, The New York Review of Books, 2 en 16 november 